\title{
Dbałość o zachowanie języka ojczystego na emigracji (na przykładzie Szkoły Polskiej w Portland, Oregon)
}

\author{
Preserving the mother tongue in exile \\ (using the example of the Polish School in Portland, Oregon)
}

Summary: The study presents research showing the possibilities of making the mother tongue/ native language available to children whose parents do not know Polish or have minimal knowledge of it. The research was conducted on the basis of the dynamics of development of the Polish School in Portland in the years 2011-2013. Using questionnaires, a survey, community interview, and questions in an interview, comprehensive information was collected from parents, students and teachers. The information concerned, among others, the following issues: the demographic outline and cultural affiliation of parents, the level of knowledge of the Polish language by parents, as well as parents', teachers' and students' beliefs about maintaining the Polish language. On the basis of the results and conclusions from the research, the author tries to indicate ways to improve the educational situation of Polonia children.

Keywords: pedagogical research, parents, inherited language, maintenance of inherited language, ethnic schools

Pielęgnowanie języka ojczystego to życiowy proces wymagający wielu poświęceń ze strony rodziców, a utrzymanie go na zadowalającym poziomie to dodatkowe wyzwanie ${ }^{1}$.

${ }^{1}$ R. Dajnowska: Preservation of Heritage Language at Community-based Program at the Polish School, Portland, Oregon. Oregon 2013, s. 6. Tłumaczenie autorki. 


\section{Wstęp}

Jako matka, a jednocześnie nauczycielka, która zarządza małą, etniczną szkołą sobotnią, dostrzegam wartość zachowania oraz pielęgnowania ojczystego języka. Widzę problemy i wyzwania, przed którymi stoją rodzice, a także nauczyciele. Jednym z większych jest próba odpowiedzi na pytanie: jak sprawić, by język ojczysty/odziedziczony był dostępniejszy dla dzieci, których rodzice nie znają języka polskiego lub znają go słabo? Wiem, że problemy, z którymi boryka się nasza szkoła, występują w wielu polskich szkołach etnicznych na terenie Stanów Zjednoczonych i w innych krajach. Różne grupy etniczne stają przed podobnymi dylematami. „Według spisu ludności przeprowadzonego w USA, w Stanach Zjednoczonych używanych jest ponad trzysta dwadzieścia dziewięć różnych języków" . Jednym z nich jest język polski, który dla swych użytkowników stał się językiem odziedziczonym. Jego pielęgnowanie to życiowy proces wymagający poświęcenia ze strony rodziców, a jego utrzymanie na zadowalającym poziomie to dodatkowe wyzwanie.

Celem moich badań stało się poszukiwanie metod i środków, które mogą ułatwić naukę języka ojczystego/odziedziczonego tym uczniom, których rodzice nie znają go już dobrze. Prowadziłam je z nadzieją, że przyczynią się do wypracowania stosownych zachowań komunikacyjnych, które pomogą dorosłym (rodzicom) oraz ich dzieciom w pielęgnowaniu języka przodków.

Jeszcze przed rozpoczęciem badań w Polskiej Szkole zdecydowano się na eksperyment edukacyjny: zauważywszy w rodzinach uczniów nasilającą się tendencję do wychowania dwujęzycznego i wielojęzycznego, zdecydowaliśmy się jako nauczyciele wprowadzić pewne zmiany w sposobach nauczania. Utworzyliśmy klasę dla uczniów, którzy nie znają języka polskiego (ucząc w niej polskiego jako drugiego języka). Padła też propozycja, by w jednej klasie uczyć języka polskiego jako drugiego — wspólnie — dzieci oraz ich rodziców.

\section{Przegląd literatury}

Spośród licznych opracowań wybrałam artykuły, które definiowały słowa klucze i pozwoliły odpowiedzieć mi na postawione wcześniej pytanie. Rozpocznę od zdefiniowania pojęcia ,język odziedziczony”, które jest pojęciem stosunkowo nowym:

2 J.S. Lee: Through the Learners' Eyes: Reconceptualizing the Heritage and Non-heritage Learner of the Less Commonly Taught Languages. „Foreign Language Annals”2005, no. 38, s. 554. 
Język odziedziczony oznacza język imigranta, rdzenny lub rodowy, który może mieć językowe, etniczne, religijne, kulturowe lub symboliczne znaczenie dla mówcy. W literaturze termin ten był używany jako synonim języka społeczności, języka etnicznego, pierwszego języka, języka podstawowego i języka ojczystego, chociaż niektórzy autorzy rozgraniczają te pojęcia ${ }^{3}$.

Terminu tego używają też inni badacze, jak: Richard Brecht i Catherine Ingold $^{4}$, Ewa Lipińska i Anna Seretny ${ }^{5}$; Adriana Val i Polina Vinogradova ${ }^{6}$ Przeprowadzili oni badania na podobny temat.

„Rodzice” i „szkoła etniczna” to kolejne kluczowe słowa. Przeprowadzono wiele badań na temat roli, jaką odgrywają rodzice w utrzymaniu języka ojczystego/odziedziczonego, kultury oraz we współtworzeniu szkół etnicznych. Postawy rodziców związane z przekazywaniem języka ojczystego swoim dzieciom bada Olena Nesteruk ${ }^{7}$. Autorka zwraca uwagę, że ,utrzymanie i utrwalanie języka ojczystego/odziedziczonego zależą od dwóch czynników: poziomu indywidualnego i poziomu grupy”. Pisze ona, że „wkład rodziców jest bardzo istotną częścią procesu utrzymania języka, ale to za mało; znaczącą rolę odgrywa współpraca z rówieśnikami z tej samej grupy etnicznej i ze społecznością etniczną" ${ }^{8}$. W podobnym badaniu Seon M. Park i Mela Sarkar ilustrują, w jaki sposób rodzice starają się zachować język koreański w dwujęzycznym Montrealu, gdzie angielski i francuski są głównymi językami ${ }^{9}$. Na Liu, Anne Musica, Silvia Koscak, Polina Vinogradova i Jacqueline López wskazują w swych badaniach wyzwania i potrzeby, jakie mogą napotykać sobotnie szkoły etniczne w USA, oraz sposoby

3 T.G. Wiley: On Defining Heritage Languages and Their Speakers. In: Heritage Languages in America. Preserving a National Resource. Eds. J.K. Peyton, D.A. Ranard, S. McGinnis. Washington 2001, s. 29.

${ }^{4}$ Zob. R. Brecht, C. Ingold: Tapping a National Resource. Heritage Languages in the United States. Washington 2002. http://www.cal.org/resources/digest/digest_pdfs/0202brecht.pdf [data dostępu: 13.01.2019].

${ }_{5}$ E. Lipinska, A. Seretny: Heritage Language in Polish Schools. „Głos Nauczyciela” / „Teacher Voice” 2012, no. 1, s. 65-67.

${ }^{6}$ Zob. A. Val, P. Vinogradova: What Is the Identity of a Heritage Language Speaker?. „Heritage Briefs Center for Applied Linguistics” 2010. http://www.cal.org/heritage/pdfs/briefs/ what-is-the-identity-of-a-heritage-language-speaker.pdf [data dostępu: 13.01.2019].

7 Zob. O. Nesteruk: Heritage Language Maintenance and Loss Among the Children of Eastern European Immigrants in the USA. ,Journal of Multilingual and Multicultural Development” 2010, no. 31 (3). http://dx.doi.org/10.1080/01434630903582722 [data dostępu: 13.01.2019].

8 Ibidem, s. 278-279.

9 Zob. S.M. Park, M. Sarkar: Parents' Attitudes toward Heritage Language Maintenance for Their Children and Their Efforts to Help Children Maintain Heritage Language: A Case Study of Korean-Canadian Immigrants. „Language, Culture, and Curriculum” 2007, no. 20 (3), s. 223235. 
zapobiegania problemom ${ }^{10}$. Podkreślają, że jednym $\mathrm{z}$ ważnych filarów, od których zależy działalność językowych szkół etnicznych, jest wsparcie rodziców. „Rodzice są integralną częścią sukcesu szkoły etnicznej i utrzymania języka ojczystego/odziedziczonego u swoich dzieci"'11. W kolejnych opracowaniach opisano polskie społeczności z trzech różnych krajów oraz metody, jakie stosuje się w celu zachowania języka polskiego jako ojczystego/odziedziczonego.

Źródła naukowe podają, że w Nowym Jorku język polski jest językiem ojczystym/ odziedziczonym dla 99999 Polaków, a w Kalifornii 22841 osób mówi po polsku ${ }^{12}$. Wśród tych społeczności podejmowane są działania zmierzające do zachowania języka przodków, nieraz nieskuteczne. W 2009 roku Aleksandra Slabisz napisała artykuł do „Nowego Dziennika” poświęcony staraniom szkół polskich w Nowym Jorku i New Jersey o utrzymanie języka polskiego. Problemy, z jakimi muszą się zmierzyć szkoły, to: spadek frekwencji, podniesienie standardu życia i zmniejszona imigracja z Polski. Autorka wskazuje, że

Polacy, którzy zdecydowali się tu zostać, są bardziej zasymilowani z amerykańskim społeczeństwem. Mówią lepiej po angielsku i często poślubiają nie-Polaków. Ich dzieci rodzą się Amerykanami, a język polski jest dla nich drugim językiem ${ }^{13}$.

Dogłębne badania, które przeprowadzili Michael Fitzgerald i Robert Dębski $^{14}$, przedstawiają rolę Internetu w procesie uczenia się języka przodków przez polskie społeczeństwo w Melbourne. Naukowcy podkreślają, że w edukacji etnicznej powinno się korzystać z technicznej wiedzy członków społeczności we wspieraniu inicjatyw pedagogicznych. Z kolei Joanna Lustańska skupiła się na analizie tożsamości etnicznej oraz stanowiska wobec języka, religii i kultury Polaków (w pierwszym i drugim pokoleniu) ${ }^{15}$, przybyłych do Kanady po 1989 roku.

${ }^{10}$ Zob. N. Liu, A. Musica, S. Koscak, P. Vinogradova, J. López: Challenges and Needs of Community-based Heritage Language Programs and How They Are Addressed. Washington 2011, s. 1-18. http://www.cal.org/heritage/pdfs/briefs/challenges-and\%20needs-of -community-based-heritage-language-programs.pdf [data dostępu: 13.01.2019].

${ }_{11}$ Zob. ibidem.

${ }_{12}$ Zob. M. Carreira, O. Kagan: The Results of the National Heritage Language Survey: Implications for Teaching, Curriculum Design, and Professional Development. „Foreign Language Annals" 2011, no. 44, s. 40-64.

${ }_{13}$ Zob. A. Slabisz: Preserving Polish Heritage and Language in School. „Nowy Dziennik” / „Polish Daily News” 2009, March 26. http://www.indypressny.org/nycma/voices/sources/ Nowy_Dziennik_Polish_Daily_News/[data dostępu: 26.01.2019].

${ }^{14}$ Zob. M. Fitzgerald, R. Debski: Internet Use of Polish Melbournians. Implications for Maintenance and Teaching. „Language Learning \& Technology” 2006, no. 10 (1), s. 99. http://llt. msu.edu/vol10num1/fitzdebski/ [data dostępu: 26.01.2019].

${ }_{15}$ Zob. J. Lustanski: Polish Canadians and Polish Immigrants in Canada: Self-identity and Language Attitude. „International Journal of the Sociology of Language” 2009, no. 199, s. 39-61. 
Na zakończenie analizy opracowań innych badaczy chciałabym wskazać najważniejsze ustalenia: by zachować język odziedziczony (nazywany też: ,językiem ojczystym”, ,językiem domowym”, ,pierwszym językiem”), by nie doszło do jego utraty, należy podejmować działania edukacyjne. Zachowanie języka przodków, jego znajomość i pielęgnowanie niosą bowiem wiele korzyści (mentalnych, lingwistycznych, socjologicznych, ekonomicznych), z czego nie zawsze zdają sobie sprawę członkowie mniejszości etnicznych, lekceważąc wysiłki szkół etnicznych na całym świecie. Nieświadomość wagi zachowania języka odziedziczonego widoczna jest czasami w braku zainteresowania rodziców przekazywaniem i pielęgnowaniem języka ojczystego, wynika też z ich słabej znajomości tegoż języka. Brak przekonania rodziców do wysiłku edukacyjnego odzwierciedla się również w niedostatecznej motywacji dziecka do nauki języka. Ważna i konieczna byłaby w tym przypadku współpraca między szkołami językowymi, środowiskami etnicznymi i okręgami szkolnymi w danym kraju.

Przegląd stanu badań pozwolił mi również na wybór odpowiednich narzędzi badawczych, które wykorzystałam w podjętych poszukiwaniach.

\section{Badania}

Badania zostały przeprowadzone w dwóch częściach: pod koniec roku szkolnego 2011/2012 i w roku szkolnym 2012/2013. Brali w nich udział rodzice (26), uczniowie (30) i nauczyciele (7). Każdy z rodziców otrzymał kwestionariusz ankiety, a 6 z nich wzięło udział w rozmowie środowiskowej. Rodzice odpowiadali na pytania podzielone na sześć podkategorii dotyczących użytkowników języka odziedziczonego, kodów komunikowania się, sytuacji komunikacyjnych, w których komunikacja przebiega z użyciem języka odziedziczonego i języka kraju przebywania, a także przekonań o roli i znaczeniu języka odziedziczonego. $Z$ kolei każdy uczeń odpowiadał na pytania zawarte $\mathrm{w}$ specjalnie dla niego przygotowanej ankiecie. $Z$ nauczycielami przeprowadzałam rozmowę/wywiad (z uszeregowanymi pytaniami). W charakterze narzędzi badawczych wykorzystałam kwestionariusz ankiety i wywiadu/rozmowy skonstruowane na podstawie danych zawartych w literaturze przedmiotu. Skorzystałam z narzędzi z badań Michaela Fitzgeralda i Roberta Dębskiego, Marii Carreiry i Olgi Kagan, Jeen S. Lee, Trini Lewis, May Bui i Huyen N. Do, Joanny Lustanski, Oleny Nesteruk, Mana S. Parka i Meli Sarkara, Mili Schwartz, Michaela Tannenbauma ${ }^{16}$,

${ }_{16}$ Zob. M. Fitzgerald, R. Debski: Internet Use of Polish...; M. Carreira, O. Kagan: The Results of the National Heritage...; J.S. Lee: Through the Learners' Eyes...; T. Lewis, M. Bui, H.N. Do: Attitudes towards Maintaining Vietnamese Heritage Language. Parents' 
dostosowując je do własnych potrzeb. Swym respondentom (rodzicom, nauczycielom i uczniom) zadawałam pytania między innymi o miejsce/kraj urodzenia, lata spędzone na emigracji, związki z kulturą (polską i amerykańską), poziom znajomości języków (polskiego i angielskiego), ich użytkowanie w różnych okresach życia, a także o znaczenie, jakie ma dla nich znajomość języka polskiego, i o przekonania na temat jego roli w ich życiu.

Mam nadzieję, że zebrane przeze mnie dane pozwolą w znacznym stopniu odpowiedzieć na postawione pytania; pomogą również rodzicom i uczniom w zachowaniu języka ojczystego/odziedziczonego.

\section{Analiza danych}

Gromadzenie informacji, zbieranie danych było bardzo interesującym, twórczym, a także obszernym procesem. Przedstawię tylko wybrane fragmenty badań uwzględniające: demografię rodziców oraz ich przynależność kulturową, znajomość języka polskiego i angielskiego przez rodziców, jak również przekonania rodziców, nauczycieli i uczniów dotyczące języka odziedziczonego.

\section{Zarys demograficzny}

Demografia pochodzenia rodziców zmieniła się od czasu powstania szkoły. W roku szkolnym 2011/2012 do Szkoły Polskiej w Portland dzieci zapisało 26 rodzin. Jedynie w 4 rodzinach oboje rodzice pochodzą z Polski i mówią po polsku; w wypadku 21 rodzin tylko jedno z rodziców mówi po polsku (w pierwszym lub drugim pokoleniu), a w rodzinie jednego ucznia tylko dziadek zna język polski. Wykres 1. przedstawia miejsca (kraje) urodzenia rodziców biorących udział w badaniach.

and Students' Perspective. Presented for the National Association for Asian and Pacific American Education and Pacific American Education 2011. http://www.csulb.edu/ tlewis2/documents/ NAAPEConference2011.pdf [data dostępu 13.01.2019]; J. Lustanski: Polish Canadians and Polish Immigrants...; O. Nesteruk: Heritage Language Maintenance...; S.M. Park, M. Sarkar: Parents' Attitudes Toward Heritage Language...; M. Schwartz, V. Moin, M. Leiken, A. Breitkopf: Immigrant Parents' Choice of a Bilingual versus Monolingual Kindergarten for Second-generation Children. Motives, Attitudes, and Factors. „International Multilingual Research Journal" 2010, no. 4; M. Tannenbaum: Viewing Family Relations through a Linguistic Lens. Symbolic Aspects of Language Maintenance in Immigrant Families. „,The Journal of Family Communication" 2005, no. 5 (3). 


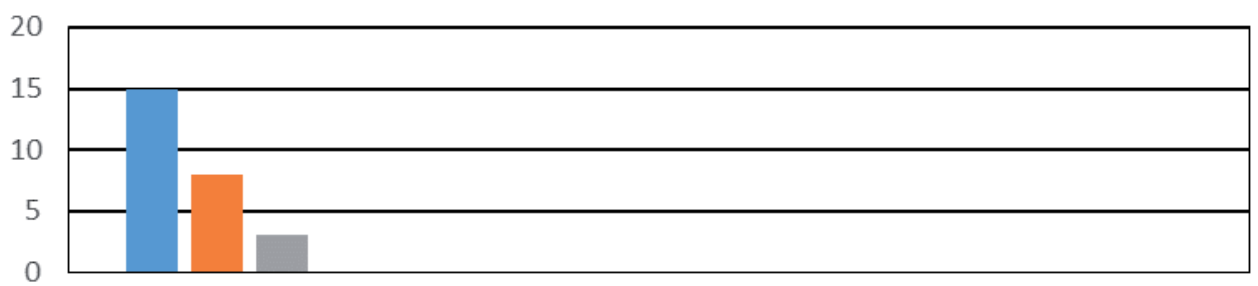

\section{Kategoria 1}

\section{Polska $\quad$ USA Inne miejsce}

Wykres 1. Miejsce urodzenia rodziców biorących udział w badaniach

Z wykresu 1. wynika, że 18 z 26 badanych rodziców urodziło się poza USA. $\mathrm{Z}$ kolei tabela 1. zawiera porównanie wieku, w jakim rodzice nie-Amerykanie przyjechali do USA, ich obecny wiek oraz liczbę lat, jaką przebywają w Ameryce. Liczba ta waha się od 9 do 31 lat, ze średnią 19,5 roku.

Tabela 1.

Wiek rodziców oraz liczba lat spędzonych w Stanach Zjednoczonych porównanie

\begin{tabular}{|c|c|c|c|}
\hline $\begin{array}{c}\text { Rodzice urodzeni } \\
\text { poza USA }\end{array}$ & $\begin{array}{c}\text { Wiek, wakim } \\
\text { przyjechali do USA }\end{array}$ & $\begin{array}{c}\text { Wiek } \\
\text { w dniu badania }\end{array}$ & $\begin{array}{c}\text { Lata spędzone } \\
\text { w USA }\end{array}$ \\
\hline 1 & 24 & 43 & 19 \\
\hline 2 & 14 & 38 & 24 \\
\hline 3 & 20 & 39 & 19 \\
\hline 4 & 23 & 43 & 20 \\
\hline 5 & 18 & 44 & 26 \\
\hline 6 & 23 & 50 & 27 \\
\hline 7 & 22 & 45 & 17 \\
\hline 8 & 25 & 42 & 10 \\
\hline 9 & 26 & 36 & 12 \\
\hline 10 & 26 & 38 & 18 \\
\hline 11 & 20 & 38 & 19 \\
\hline 12 & 25 & 44 & 35 \\
\hline 13 & 9 & 44 & 12 \\
\hline 14 & 26 & 38 & 9 \\
\hline 15 & 26 & 35 & 22 \\
\hline 16 & 22 & 44 & $\mathbf{1 9 , 6}$ \\
\hline 17 & 5 & 36 & \\
\hline Średnia & $\mathbf{1 8}$ & & 31 \\
\hline & & & 38 \\
\hline
\end{tabular}


Do ciekawych wniosków prowadzą wyniki przedstawione w tabeli 2. Pokazują one poziom więzi, jakie odczuwają rodzice z polską i amerykańską kulturą. Uznając, że deklaracja więzi z kulturą polską w 50\% i więcej jest znacząca, można stwierdzić, że ponad $68 \%$ rodziców biorących udział w badaniach czuje się związanych z polską kulturą. Więź z kulturą amerykańską jest jednak zdecydowanie silniejsza, ponieważ utożsamiało się z nią aż $95,5 \%$ badanych. Można też dodać, że porównanie wyników dotyczących utożsamiania się z kulturą amerykańską lub polską wskazuje u części respondentów tzw. podwójną tożsamość (odczuwanie więzi z kulturą polską i amerykańską).

Tabela 2.

Utożsamianie się z polską i amerykańską kulturą (według samych rodziców)*

\begin{tabular}{|l|c|c|c|c|c|c|c|c|c|c|}
\hline \multirow{2}{*}{ Więź } & \multicolumn{2}{|c|}{ Brak więzi } & \multicolumn{2}{c|}{$\begin{array}{c}\text { Odczuwam } \\
\text { w małym procencie }\end{array}$} & \multicolumn{2}{c|}{$\begin{array}{c}\text { Odczuwam } \\
\text { w 50\% }\end{array}$} & \multicolumn{2}{c|}{$\begin{array}{c}\text { Odczuwam } \\
\text { silną więź }\end{array}$} & \multicolumn{2}{c|}{$\begin{array}{c}\text { Całkowicie się } \\
\text { identyfikuję }\end{array}$} \\
\cline { 2 - 11 } & liczba & $\%$ & liczba & $\%$ & liczba & $\%$ & liczba & $\%$ & liczba & $\%$ \\
\hline $\begin{array}{l}\text { Z kulturą } \\
\text { polską }\end{array}$ & 1 & 4,54 & 6 & 27,27 & 5 & 22,72 & 3 & 13,63 & 7 & 31,81 \\
\hline $\begin{array}{l}\text { Z kulturą } \\
\text { amerykańską }\end{array}$ & 0 & 0 & 1 & 4,54 & 7 & 31,81 & 6 & 27,27 & 8 & 36,36 \\
\hline
\end{tabular}

* W badaniu brało udział 22 rodziców.

\section{Poziom znajomości języka polskiego}

Poziom znajomości języka polskiego rodziców zmienił się znacznie od czasu, kiedy w 1995 roku powstała szkoła. Uczniowie nie mają w domu takiego samego doświadczenia w obcowaniu z językiem polskim, jak to było prawie 20 lat temu. Rodzice znają język polski jako język ojczysty ( $45,45 \%$ badanych) albo go nie znają lub są na poziomie początkowym (45,41\% badanych). Znajomość języka angielskiego lokuje się na poziomie zaawansowanym $-\mathbf{4 0 , 0 9 \%}$ badanych, lub na poziomie języka ojczystego $\mathbf{- 5 4 , 5 5 \%}$. Wynika z tego, że rodzice dzieci ze Szkoły Polskiej w połowie znają bardzo dobrze język polski, a prawie wszyscy znają język angielski na bardzo zaawansowanym poziomie.

Liczba rodziców, którzy zadeklarowali znajomość języka polskiego na poziomie profesjonalnym ${ }^{17}$ we wszystkich sprawnościach językowych (mówienie, czytanie, słuchanie i pisanie - 45,45\%, por. tabelę 3.), jest identyczna z liczbą osób dorosłych (w wieku 25 lat i więcej), które komunikują się jednocześnie w języku polskim i angielskim (45,45\%, por. tabelę 4.). Może to oznaczać, że w procesie asymilacji rodzice nieurodzeni w Stanach, mieszkający w USA co najmniej 9 lat, stali się osobami dwujęzycznymi (lub w kilku przypadkach — trójjęzycznymi).

\footnotetext{
${ }^{17}$ Znajomość na poziomie języka ojczystego.
} 
Tabela 3.

Poziom kompetencji językowej (w zakresie znajomości języka polskiego, angielskiego) deklarowany przez rodziców

\begin{tabular}{|l|c|c|c|c|c|c|c|c|c|c|}
\hline \multirow{2}{*}{$\begin{array}{c}\text { Poziom } \\
\text { znajomości } \\
\text { języka }\end{array}$} & \multicolumn{2}{|c|}{ Zerowy } & \multicolumn{2}{c|}{ Początkujący } & \multicolumn{2}{c|}{$\begin{array}{c}\text { Średnio } \\
\text { zaawansowany }\end{array}$} & \multicolumn{2}{c|}{ Zaawansowany } & \multicolumn{2}{c|}{ Profesjonalny } \\
\cline { 2 - 11 } & liczba & $\%$ & liczba & $\%$ & liczba & $\%$ & liczba & $\%$ & liczba & $\%$ \\
\hline $\begin{array}{l}\text { Kompetencja } \\
\text { w języku } \\
\text { polskim }\end{array}$ & 3 & 13,63 & 7 & 31,81 & 1 & 4,54 & 1 & 4,54 & 10 & $\mathbf{4 5 , 4 5}$ \\
\hline $\begin{array}{l}\text { Kompetencja } \\
\text { w języku } \\
\text { angielskim }\end{array}$ & 0 & 0 & 0 & 0 & 1 & 4,54 & 9 & 40,9 & 12 & $\mathbf{5 4 , 5 5}$ \\
\hline
\end{tabular}

Tabela 4.

Komunikacja rodziców w językach polskim i angielskim w pięciu okresach życia*

\begin{tabular}{|c|c|c|c|c|}
\hline \multirow{2}{*}{ Lata życia } & \multicolumn{4}{|c|}{ Języki } \\
\cline { 2 - 5 } & polski & angielski & $\begin{array}{c}\text { polski } \\
\text { i angielski }\end{array}$ & $\begin{array}{c}\text { inny } \\
\text { język ojczysty }\end{array}$ \\
\hline \multirow{2}{*}{$0-5$} & $13 / 22$ & $7 / 22$ & $0 / 22$ & $2 / 22$ \\
\cline { 2 - 5 } & $59,09 \%$ & $31,81 \%$ & $0 \%$ & $9,09 \%$ \\
\hline \multirow{2}{*}{$6-12$} & $10 / 22$ & $8 / 22$ & $3 / 22$ & $1 / 22$ \\
\cline { 2 - 5 } & $45,45 \%$ & $36,36 \%$ & $13,63 \%$ & $4,54 \%$ \\
\hline \multirow{2}{*}{$13-18$} & $10 / 22$ & $8 / 22$ & $3 / 22$ & $1 / 22$ \\
\cline { 2 - 5 } & $45,45 \%$ & $36,36 \%$ & $13,63 \%$ & $4,54 \%$ \\
\hline \multirow{2}{*}{$18-25$} & $7 / 22$ & $9 / 22$ & $6 / 22$ & $4 / 22$ \\
\cline { 2 - 5 } & $31,81 \%$ & $40,90 \%$ & $27,27 \%$ & - \\
\hline 25 lat i więcej & $0 / 22$ & $12 / 22$ & $10 / 22$ & - \\
\cline { 2 - 5 } & $0 \%$ & $54,54 \%$ & $\mathbf{4 5 , 4 5 \%}$ & $-2 / 22$ \\
\hline
\end{tabular}

* Cyfra po ukośniku oznacza liczbę rodziców deklarujących sposób komunikowania się w różnych okresach życia.

Poglądy rodziców, nauczycieli, uczniów

Tabele 5.-8. pokazują interesujące zestawienie informacji pozyskanych od rodziców, nauczycieli i uczniów. Tabela 5. przedstawia porównanie przekonań rodziców, nauczycieli i uczniów co do roli znajomości języka ojczystego/odziedziczonego. Według 95\% rodziców utrzymanie znajomości języka polskiego jest ważne, to samo odczuwa $100 \%$ nauczycieli i $87 \%$ uczniów. Bardzo wysoki odsetek rodziców (95\%) i nauczycieli (100\%) uważa, że znajomość języka polskiego może pomóc ich dzieciom zachować swoją kulturę, a $85 \%$ rodziców 
i 100\% nauczycieli uznaje, że znajomość języka polskiego pozwala dzieciom na komunikację ze starszymi członkami rodziny (dziadkami).

Tabela 5 .

Znaczenie znajomości języka polskiego dla rodziców, nauczycieli, uczniów

\begin{tabular}{|l|c|c|c|}
\hline \multicolumn{1}{|c|}{ Zn \%] } \\
\hline Zachowanie języka polskiego jest ważne & Rodzice & Nauczyciele & Uczniowie \\
\hline $\begin{array}{l}\text { Znajomość języka polskiego pomaga } \\
\text { w zachowaniu polskiej kultury }\end{array}$ & 95 & 100 & 87 \\
\hline $\begin{array}{l}\text { Znajomość języka polskiego pozwala } \\
\text { porozumiewać się ze starszymi osobami }\end{array}$ & 85 & 100 & - \\
\hline
\end{tabular}

Tabela 6. prezentuje argumenty świadczące o dużej roli znajomości przez dzieci języka ojczystego ich rodziców. Oboje rodzice i nauczyciele zgadzają się w 100\%, że znajomość języka ojczystego rodziców jest ważna. Rodzice rozumieją też, że ich dziedzictwo i komunikacja z rodziną oraz przyjaciółmi w Polsce są równie ważne ( $83,3 \%$ odpowiedzi). Dorośli wiedzą również, że język jest wartością: stanowi część kultury, może dawać w życiu korzyści płynące z jego znajomości jako środka porozumiewania się (50\% respondentów), a 33,3\% z nich uważa, że znajomość języka może korzystnie wpłynąć na przyszłość.

Tabela 6.

\section{Ranga i rola znajomości języka polskiego dla rodziców i nauczycieli}

$$
\text { [w \%] }
$$

\begin{tabular}{|l|c|c|}
\hline \multicolumn{1}{|c|}{ Pytania i argumenty } & Rodzice - $\mathrm{AR}^{\mathrm{a})}$ & ${\text { Nauczyciele }-\mathrm{RN}^{\mathrm{b}} \text { ) }}$ \\
\hline $\begin{array}{l}\text { Czy ważne jest dla ciebie, by twoje dziecko } \\
\text { znało język polski? }\end{array}$ & 100 & 100 \\
\hline Rola języka: stanowi dziedzictwo & 83,3 & - \\
\hline $\begin{array}{l}\text { Pozwala komunikować się z rodziną } \\
\text { i znajomymi }\end{array}$ & 88,3 & - \\
\hline Jest częścią odziedziczonej kultury & 50 & - \\
\hline Znajomość języka daje korzyści & 50 & - \\
\hline Znajomość języka może pomóc w przyszłości & 33,3 & - \\
\hline $\begin{array}{l}\text { Język stymuluje rozwój, stanowi wartość } \\
\text { emocjonalną }\end{array}$ & 16,6 & - \\
\hline
\end{tabular}

Objaśnienia: a) AR — ankieta rodziców, b) RN — rozmowa z nauczycielem.

Następne zestawienie, tabela 7., pokazuje dane zebrane w AR (ankietach rodziców) na temat pielęgnacji języka. 95\% rodziców zgadza się lub zdecydowanie się zgadza, że Szkoła Polska pomaga w zachowaniu języka polskiego, 85\% uważa, że w tym procesie ważne jest zaangażowanie rodziców. 
Tabela 7.

Zachowanie języka polskiego (skala Likerta ${ }^{18}$ )

\begin{tabular}{|l|c|c|c|c|c|c|c|c|c|c|}
\hline \multirow{2}{*}{ Zachowanie języka } & $\begin{array}{c}\text { Zdecydowa- } \\
\text { nie się nie } \\
\text { zgadzam }\end{array}$ & \multicolumn{2}{c|}{$\begin{array}{c}\text { Nie zga- } \\
\text { dzam się }\end{array}$} & \multicolumn{2}{c|}{ Nie wiem } & \multicolumn{2}{|c|}{ Zgadzam się } & \multicolumn{2}{c|}{$\begin{array}{c}\text { W pełni się } \\
\text { zgadzam }\end{array}$} \\
\cline { 2 - 12 } & liczba & $\%$ & liczba & $\%$ & liczba & $\%$ & liczba & $\%$ & liczba & $\%$ \\
\hline $\begin{array}{l}\text { Szkoła Polska pomaga } \\
\text { w zachowaniu języka } \\
\text { polskiego }\end{array}$ & 0 & 0 & 0 & 0 & $1 / 20$ & 5 & $6 / 20$ & $\mathbf{3 0}$ & $13 / 20$ & $\mathbf{6 5}$ \\
\hline $\begin{array}{l}\text { Wolontariat rodziców } \\
\text { w szkole pomaga dzieciom } \\
\text { w utrzymaniu języka }\end{array}$ & 0 & 0 & $3 / 20$ & 15 & 0 & 0 & $7 / 20$ & $\mathbf{3 5}$ & $10 / 20$ & $\mathbf{5 0}$ \\
\hline
\end{tabular}

Z kolei dane uzyskane od rodziców w wywiadzie (WR) i z ankiet uczniów (AU) prezentuje tabela 8 . Analiza danych wskazuje, że rodzice muszą podjąć wiele działań, by wpłynąć na zachowanie języka odziedziczonego. $100 \%$ rodziców uznaje, że należy do nich zapisanie swych dzieci do Szkoły Polskiej. Niestety, aż 70\% uczniów odczuwa te działania jako przymus (mówią, że rodzice zmuszają ich do uczęszczania do polskiej szkoły). Dorośli pomagają też dzieciom uczyć się języka polskiego, rozmawiając i czytając po polsku $(66,6 \%$ respondentów) oraz pomagając $\mathrm{w}$ odrabianiu lekcji (50\% badanych). Te działania potwierdzają uczniowie, gdy mówią ( $77 \%$ odpowiedzi), że rodzice czytają im po polsku, a 93\% uczniów stwierdza, że w domu mają książki w języku polskim.

Tabela 8.

Działania wspomagające zachowanie języka polskiego — odpowiedzi rodziców i uczniów

\begin{tabular}{|l|c|l|c|}
\hline \multicolumn{1}{|c|}{ Rodzice (wywiad rodziców) } & $\%$ & \multicolumn{1}{|c|}{ Uczniowie (ankieta ucznia) } & $\%$ \\
\hline Zapisuję dziecko do Szkoły Polskiej & 100 & $\begin{array}{l}\text { Rodzice zmuszają nas do chodzenia do } \\
\text { Szkoły Polskiej }\end{array}$ & 70 \\
\hline $\begin{array}{l}\text { Mówię po polsku, czytam po polsku } \\
\text { każdego dnia }\end{array}$ & 66,6 & $\begin{array}{l}\text { Mama albo tata czyta nam po polsku } \\
\text { w domu }\end{array}$ & 77 \\
\hline $\begin{array}{l}\text { Pomagam w odrabianiu zadań domo- } \\
\text { wych w języku polskim }\end{array}$ & 50 & - & - \\
\hline $\begin{array}{l}\text { Bierzemy udział we mszy św. po pol- } \\
\text { sku, oglądamy filmy po polsku }\end{array}$ & 33,3 & - & - \\
\hline $\begin{array}{l}\text { Wyjeżdżamy na wakacje do Polski, } \\
\text { rozmawiamy z dziadkami, mamy gry } \\
\text { komputerowe, puzzle, Internet po pol- } \\
\text { sku, polską muzykę }\end{array}$ & 16,6 & Mamy polskie książki w domu & 93 \\
\hline
\end{tabular}

18 Pięciostopniowa skala, którą wykorzystuje się w kwestionariuszach ankiet i wywiadach kwestionariuszowych, by otrzymać odpowiedź dotyczącą stopnia akceptacji zjawiska i poglądu. Nazwa skali pochodzi od nazwiska Rensisa Likerta. 


\section{Wnioski końcowe}

Z analizy zebranych od rodziców, nauczycieli i uczniów danych można wyciągnąc następujące wskazówki praktyczne dla wszystkich mieszkających poza Polską i pragnących zachować język polski:

1. Dla rodziców: staraj się mówić w domu po polsku, oglądaj polskie filmy, słuchaj polskich piosenek, czytaj polskie książki i słuchaj ich w wersji audio oraz utrzymuj kontakt z rodziną w Polsce. Daj dziecku przykład: motywuj do pracy mimo popełnianych przez nie błędów, używaj polskich aplikacji internetowych, polskich stron internetowych, rozmawiaj po polsku ze współmałżonkiem.

2. Dla ucznia: bierz udział w zajęciach języka polskiego, korzystaj ze zbiorów bibliotecznych, uczestnicz w szkolnych wydarzeniach i uroczystościach.

3. Dla nauczycieli: wymyślaj zadania domowe, które będą aktywnie motywować dzieci do posługiwania się językiem polskim w pisaniu kartek, listów, e-maili do rodziny w Polsce. Niech starsze klasy korzystają z Internetu jako narzędzia przydatnego do zbierania informacji.

4. Dla dyrektorów: twórz klasy łączone — ,język polski jako drugi” — dla uczniów i rodziców, wzbogacaj szkolną biblioteczkę w audiowizualne pozycje z Polski, organizuj warsztaty dla rodziców i rozmawiaj z nimi motywująco podczas zapisu dziecka do szkoły.

5. Dla wszystkich: bierz udział w uroczystościach polonijnych, organizuj spotkania - zabawy dla polskich dzieci, organizuj spotkania przy herbatce dla rodziców, uczestnicz w kościelnych uroczystościach, mów po polsku przy każdej sposobności.

6. Jedź do Polski - to najskuteczniejsza droga do lepszego poznania języka polskiego i polskiej kultury.

Podejmowanie wskazanych działań przynosi rezultaty o charakterze nagrody, a „najlepszą nagrodą dla rodzica jest to, kiedy słyszy swoje dziecko mówiące w ojczystym języku. Znajomość ojczystego/odziedziczonego języka jest największym skarbem, jaki możesz przekazać swojemu dziecku"19.

\section{Bibliografia}

Carreira M., Kagan O.: The Results of the National Heritage Language Survey: Implications for Teaching, Curriculum Design, and Professional Development. „Foreign Language Annals” 2011, no. 44, s. $40-64$.

${ }^{19}$ R. Dajnow ska: Preservation of Heritage Language..., s. 40. 
Dajnowska R.: Preservation of Heritage Language at Community-based Program at the Polish School, Portland, Oregon [Utrzymanie języka ojczystego w programie społeczności Szkoły Polskiej $w$ Portland]. Oregon 2013.

Lee J.S.: Through the Learners'Eyes. Reconceptualizing the Heritage and Non-heritage Learner of the Less Commonly Taught Languages. „Foreign Language Annals” 2005, no. 38, s. 554-563.

Lipinska E., Seretny A.: Heritage Language in Polish Schools. „Głos Nauczyciela” / „Teacher Voice" 2012, no. 1, s. 65-67.

Lustanski J.: Polish Canadians and Polish Immigrants in Canada: Self-identity and Language Attitude. „International Journal of the Sociology of Language” 2009, no. 199, s. 39-61.

Park S.M., Sarkar M.: Parents'Attitudes toward Heritage Language Maintenance for Their Children and Their Efforts to Help Children Maintain Heritage Language: A Case Study of Korean -Canadian Immigrants. „Language, Culture, and Curriculum” 2007, no. 20 (3), s. 223-235.

Schwartz M., Moin V., Leikin M., Breitkopf A.: Immigrant Parents' Choice of a Bilingual versus Monolingual Kindergarten for Second-generation Children. Motives, Attitudes, and Factors. „International Multilingual Research Journal” 2010, no. 4, s. 107-124.

Tannenbaum M.: Viewing Family Relations through a Linguistic Lens. Symbolic Aspects of Language Maintenance in Immigrant Families. „The Journal of Family Communication” 2005, no. 5 (3), s. $229-252$.

Wiley T.G.: On Defining Heritage Languages and Their Speakers. In: Heritage Languages in America. Preserving a National Resource. Eds. J.K. Peyton, D.A. Ranard, S. McGinnis. Washington 2001, s. 29-36.

\section{Źródła internetowe}

Brecht R., Ingold C.: Tapping a National Resource. Heritage Languages in the United States. Washington 2002. http://www.cal.org/resources/digest/digest_pdfs/0202brecht.pdf [data dostępu: 13.01.2019].

Fitzgerald M., Debski R.: Internet Use of Polish Melbournians. Implications for Maintenance and Teaching. „Language Learning \& Technology” 2006, no. 10 (1), s. 87-109. http://llt.msu. edu/vol10num1/fitzdebski/ [data dostępu: 26.01.2019].

Lewis T., Bui M., Do H.N.: Attitudes towards Maintaining Vietnamese Heritage Language: Parents' and Students' Perspective. Presented for the National Association for Asian and Pacific American Education and Pacific American Education 2011. http://www.csulb.edu/ tlewis2/documents/NAAPEConference2011.pdf [data dostępu: 13.01.2019].

Liu N., Musica A., Koscak S., Vinogradova P., López J.: Challenges and Needs of Community-based Heritage Language Programs and How They Are Addressed. Washington 2011, s. 1-18. http://www.cal.org/heritage/pdfs/briefs/challenges-and\%20needs-of-community-ba sed-heritage-language-programs.pdf [data dostępu: 13.01.2019].

Nesteruk O.: Heritage Language Maintenance and Loss among the Children of Eastern European Immigrants in the USA. „Journal of Multilingual and Multicultural Development” 2010, no. 31 (3), s. 271-286. http://dx.doi.org/10.1080/01434630903582722 [data dostępu: 13.01.2019].

Slabisz A.: Preserving Polish Heritage and Language in School. „Nowy Dziennik” / „Polish Daily News" 2009, March 26. http://www.indypressny.org/nycma/voices/sources/Nowy_Dziennik_ Polish_Daily_News/ [data dostępu: 26.01.2019].

Val A., Vinogradova P.: What Is the Identity of a Heritage Language Speaker?. „Heritage Briefs Center for Applied Linguistics" 2010. http://www.cal.org/heritage/pdfs/briefs/what-is-the -identity-of-a-heritage-language-speaker.pdf [data dostępu: 13.01.2019]. 